\title{
SPELLING BEE GAME IN STUDENTS' VOCABULARY ACHIEVEMENT
}

\author{
${ }^{\# 1}$ Siti Syafi'atul Qomariyah, ${ }^{2}$ Baiq Zuhrotun Nafisah \\ ${ }^{\# 1}$ English Lecturer, FBMB, UNDIKMA, Indonesia \\ ${ }^{* 2}$ English Lecturer, FBMB, UNDIKMA, Indonesia
}

Corresponding Author Email: sitisyafiatulqomariyah@ikipmataram.ac.id

\begin{abstract}
A B S T R A C T S
Finding the effect of Spelling Bee Game in students' vocabulary achievement is aimed in this research. Quasi-experimental with nonequivalent control group design as the research design. The population of the study was the first-grade students of MTs. Darul Qur'an consisted of two classes. The samples were 22 students of VII D class as the experimental group, and 22 students of VII C class as the control group so the total of the sample was 44 students. They were chosen by using the purposive sampling technique. The experimental group was treated by Spelling Bee Game, and the control group was treated by Crossword puzzle Game that is usually used by the teacher. The instrument was a vocabulary test. Then, SPSS was used to analyze the data. 67.8 was the mean score of post-test in the experimental group while 60.8 was the control group and the score of t-test was 2,359 was higher than the score of t-table was 2,021 at the level significance of 5\%. It means that the Spelling Bee was the alternative game to teach vocabulary.
\end{abstract}

\begin{tabular}{l}
\hline A R T I C L E I N F O \\
\hline Article History: \\
Received: October, 2020
\end{tabular}

Revised: November, 2020

Published: December, 2020

Keywords:

Spelling Bee Game,

Vocabulary Achievement,

How to cite: Qomariyah, S., \& Nafisah, B. (2020). Spelling Bee Game in Students' Vocabulary Achievement. Jo-ELT (Journal of English Language Teaching) Fakultas Pendidikan Bahasa \& Seni Prodi Pendidikan Bahasa Inggris IKIP, 7(2), 89-95. doi:https://doi.org/10.33394/jo-elt.v7i2.3200

\section{INTRODUCTION}

Lack of vocabulary, difficulty to spell, pronounce, and memorize the meaning of words were problems that were faced by students of MTs. Darul Qur'an. The students often get different interpretations of the teacher's elaboration. Logically, without vocabulary, nothing can be conveyed. Vocabulary takes a very important aspect when a new language is applied, especially if the learners want to be able to speak the language. Thornbury (2002) stated that the main subject usually teaches at school is English, it is not easy to learn it because it has elements such as vocabulary.

Vocabulary is a basic one in language. Why vocabulary is needed? Because when learners could listen, write, speak, and read, shall have sufficient vocabulary. Cameron (2001) said when people understand a word it means they can recognize and see it. So, in applying good sentences people should understand and know deeply the meaning of vocabulary.

Vocabulary achievement is not easy. When someone is a baby, this time is processing start. Basically, their mother tongue is the first language. The simple word when they listen from someone utterance as the way they mastery vocabulary.

There are two kinds of vocabulary dealing with Hiebert \& Kamil (2005) namely; (a). Receptive Vocabulary; when listened to and read a set of words people could determine to mean individually. In using words, students feel difficult or lack known these words. Students 
may determine the meaning of words individually, even they didn't know the differences. Especially, the individual words didn't directly use. However, these words have Been found individually, they admit them, even imperfectly beautiful. (b). Productive Vocabulary; when people applied words in writing and speaking individually is called productive vocabulary. It is familiar usually used. Based on the explanation above, Receptive vocabulary is the words that you can understand when you hear and read. Productive vocabulary is the word that can be used to express yourself in speaking and writing.

In the assessment of vocabulary, Read (2000) stated as, in any test-design project, we first need to be clear about what the purpose of a lexical inferencing test is. The literature I have just reviewed indicates at least three possible purposes: research studies that focus on the process of inferencing normally require elaborated responses from the subjects, reflecting the thinking that they engage in as they try to hard work the meaning of the recognizing word. On the other hand, for practical assessment purposes, it may be necessary to use test items that can be given a score more easily. One obvious method is to have multiple-choice items in which the test-takers select the option that fits most closely their inference about what each word means. However, this and other types of the objective-test item may work against the spirit of what the learners are being asked to do when they make inferences, particularly if it implies that there is one wrong answer for each word. There is a case for encouraging the test-takers to construct a response that expresses what they have inferred about the target word. This in turn means that, especially with lower proficiency learners, they should have the opportunity to respond in their first language rather than through L2. Thus, the convenience of scoring objective test items has to be balanced against the more time-consuming process of rating responses composed by the test-takers themselves. It can be argued that the latter approach would yield results that more validly reflect the quality of the learners' inferences. This is a clear example of a decision about test design that has to be taken in light of the assessment purpose.

In solving the problem above, Spelling Bee game is a strategy that will be applied. Spelling Bee is not only about how to think process but also how to memorize words or letter in kind of word. Besides, it is a good alternative game to practice students in Spelling skill. According to Wright (2006) stated a contest in which people are eliminated when they failed to spell correctly is called Spelling Bee game. In Spelling Bee, it is not only about memorizing but also how to process in thinking words. There are many clues in answering word that is accepted by students namely: part of speech, how to pronounce, how to combine word become sentence, etc.

There are four steps in implementing the Spelling Bee (Kagan, 2009) as follows: (a). Students seat face to face, (b). Every student has gotten peace and board game, (c). Students cannot cheat each other and another becomes the receiver, (d). One student becomes the sender and arranges the game. The partner becomes the receiver and only receives orally. To goal this game, students must speak fluently, grammatically correct, and good pronunciation.

Spelling Bee game is practicing in several steps : (a) Group A and B are chosen in this game, (b) Teacher give many themes on paper to the students including usually around them, for example, "Daily activity, family, etc", it distributes, give time for students to remind those words. To avoid students will get the mistake of Spelling words, the teacher practice Spelling word first and students follow together later, (c) Teacher should be ensuring that students are ready this game, then students stand up and make a line dealing with group agreement. Group A is first and group B is second, score of 18 is gotten for students who stand up in line position and get the first chance to spell the word, her/his group will get a 100 score if spell correctly and get 0 incorrect. The next group will follow this way and each student turn to the backline if she/he has finished the spell, (d) The highest point is a winner. 
Many researchers have conducted such as first, Mayasari et al (2019) in finding research the Spelling Bee gives positive effect in students' learning vocabulary, it can be shown by the score of post-test highest. Dealing with students' perception, this game can help the student in improving vocabulary mastery using ICD-10, even this game is new for them. Students also feel fun when they studied vocabulary and applied Spelling Bee using ICD-10. Students also have high motivation in learning vocabulary and applied Spelling Bee using ICD-10. So the conclusion of this research, the alternative hypothesis is accepted. Second, Rohmawati (2015) has researched with finding students be able to spell the word correctly when they implemented Spelling Bee in learning vocabulary. In this research, the data is analyzed by the questionnaire. It can show that the result of students' agreement was 99,24\% when they give positive impact, meanwhile, students who give negative impact was $0.76 \%$. So the researcher recommends it become one of the games that can be an alternative teaching strategy in teaching vocabulary. It can make students feel a fun atmosphere in the classroom, especially in vocabulary class.

\section{RESEARCH METHOD \\ Research Design}

The quantitative approach is used in this study. Sugiyono (2017) said the quantitative approach is scientific principles that are concrete or empirical, objective, measurable, rational, and systematic is part of a scientific method. The study applied quasi-experimental with a non-equivalent control group design. Sugiyono (2017) states that quasi-experimental is developing of true experimental design. According to Sugiyono (2017), non-equivalent control group design is a design that includes two groups while the experimental group and control group, in this research not chosen by random.

\section{Population and Sample}

The population of this research is the whole first-grade students of MTs Darul Qur'an in the academic year 2019, which consists of four classes with a total number of 94 students. Based on the total number of the population, the researchers took two classes as the sample of this research; experimental and control class.

The researchers took the sample from the population at MTs Darul Qur'an by purposive sampling technique. Sugiyono (2016) Purposive sampling is a sampling technique with certain considerations. The researchers made judgments from the observation. VII C class as the control group and VII D class were taken as the experimental group based on the observation. Because during the observation, the researchers saw VII C class was an active class when the researchers did the observation this class gave good feedback during the teaching-learning process and VII D class was a less active class, where the students found out some difficulties to give feedback during teaching and learning process. There were 22 students of VII C class as the control group and 22 students of VII D class as the experimental group. So, the researchers took 44 students as the sample in this research.

\section{Instruments}

In this research, the research instrument used was the vocabulary test in the form of multiple choice.

\section{Data Analysis}

Procedures of data analysis were techniques that were used by the researcher in analyzing the data that has Been collected. In this study, the researcher used SPPS software to analyze the data (Descriptive analysis and Inferential Statistic) 


\section{RESEARCH FINDINGS AND DISCUSSION Research Findings}

This part was the result of the pre-test before teaching using Spelling Bee game. The result of the data analysis showed the mean score is 41.45 , the mode score is 36 , the median score is 40,00 , the standard deviation is 7.36 . The following data frequency of distribution was created based on steps of data analysis.

Table 1

Descriptive Analysis pre-test and post test of Experimental Group

\begin{tabular}{|l|r|r|}
\hline & \multicolumn{1}{|c|}{ Pretest } & \multicolumn{1}{|c|}{ Posttest } \\
\hline N Valid & 22 & 22 \\
\multicolumn{1}{|c|}{ Missing } & 0 & 0 \\
Mean & 41.45 & 65.45 \\
Median & 40.00 & 64.00 \\
Mode & 36 & 56 \\
Std. Deviation & 7.360 & 10.368 \\
Minimum & 32 & 48 \\
Maximum & 56 & 84 \\
Sum & 912 & 1440 \\
\hline
\end{tabular}

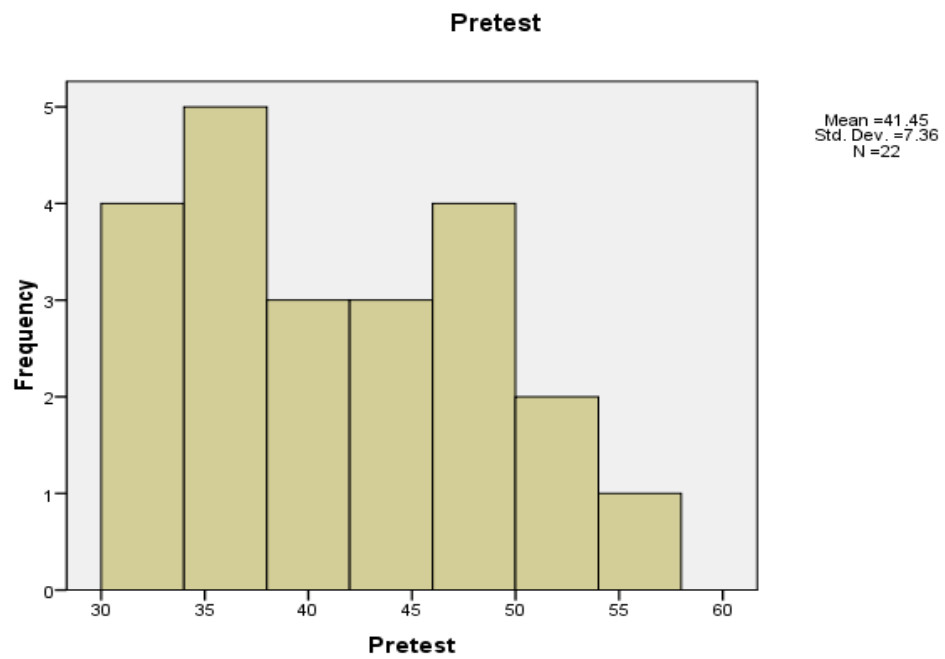

Figure 1. Histogram of Pre-test

Based on figure 1, it was easier for most people to comprehend the meaning of the data presented in a picture than in a table. The results can be seen that the score in pre-test; there were 4 students obtained score 32, 5 students obtained 36, 3 students obtained 40, 3 students obtained 44, 4 students obtained 48, 2 students obtained 52 and 1 student obtained 56. From the histogram above, it can be seen the total of data or $\mathrm{N}$ in the experimental group consists of 22 students, the mean score was 41.45 and the standard deviation (std. deviation) was 7.36 . 
In order to know students' scores after the treatment, the researchers gave post-test, then the researcher got the score of the post-test after that the researcher calculated it by using descriptive analysis. The histogram of the post-test of the experimental group was shown in figure 2.

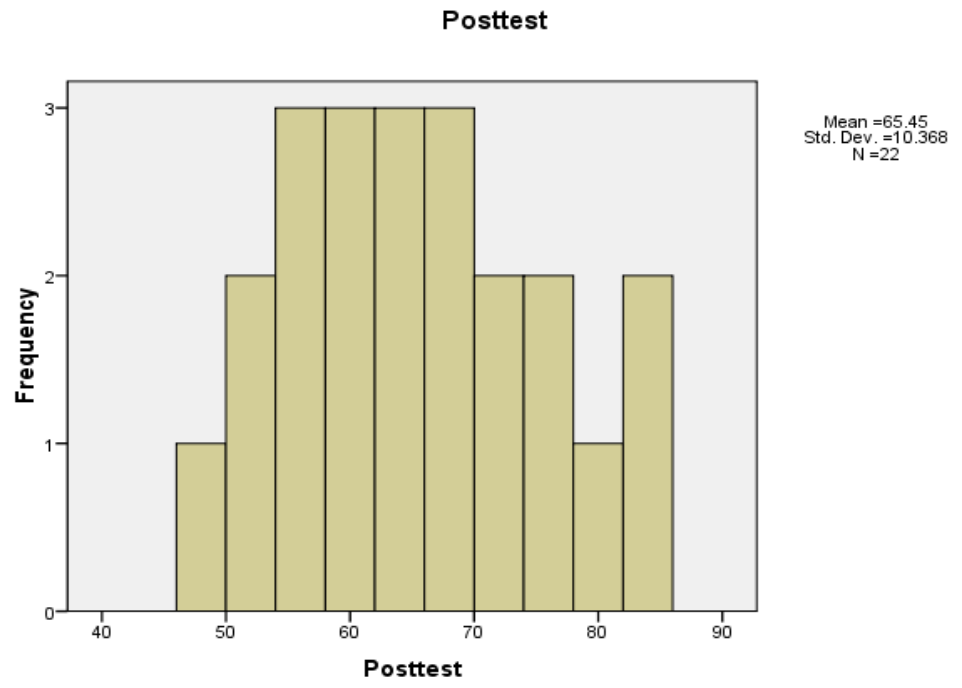

Figure 2. Histogram of Post-test

The results can be seen in figure 2. There was 1 student obtain score 48, 2 students obtain 52, 3 students obtained 56, 3 students obtained 60, 3 students obtained 64, 3 students obtained 68, 2 students obtained 72, 2 students obtained 76, 1 student obtained 80, and 2 students obtained 84. From the histogram above it can be seen the total of data or $\mathrm{N}$ in the experimental group consists of 22 students, the mean score was 65.45 and the standard deviation (std. deviation) was 10.368 .

To answer the hypothesis the researchers analyzed the t-test using SPSS. The result of the analysis can be seen on table 2 .

Table 2

T-test

\begin{tabular}{|c|c|c|c|c|c|c|c|c|c|c|}
\hline \multicolumn{11}{|c|}{ Independent Samples Test } \\
\hline & & \multicolumn{2}{|c|}{$\begin{array}{c}\text { Levene's Test for } \\
\text { Equality of } \\
\text { Variances } \\
\end{array}$} & \multicolumn{7}{|c|}{ t-test for Equality of Means } \\
\hline & & \multirow[b]{2}{*}{$\mathrm{F}$} & \multirow[b]{2}{*}{ Sig. } & \multirow[b]{2}{*}{$t$} & \multirow[b]{2}{*}{$\mathrm{df}$} & \multirow{2}{*}{$\begin{array}{c}\text { Sig. } \\
\text { (2-tailed) }\end{array}$} & \multirow{2}{*}{$\begin{array}{c}\text { Mean } \\
\text { Difference }\end{array}$} & \multirow{2}{*}{$\begin{array}{l}\text { Std. Error } \\
\text { Difference }\end{array}$} & \multicolumn{2}{|c|}{$\begin{array}{l}95 \% \text { Confidence Interva } \\
\text { of the Difference }\end{array}$} \\
\hline & & & & & & & & & Lower & Upper \\
\hline \multirow[t]{2}{*}{ Score } & $\begin{array}{l}\text { Equal variances } \\
\text { assumed }\end{array}$ & .022 & .883 & 2.359 & 42 & .023 & 7.273 & 3.084 & 1.050 & 13.496 \\
\hline & $\begin{array}{l}\text { Equal variances not } \\
\text { assumed }\end{array}$ & & & 2.359 & 41.968 & .023 & 7.273 & 3.084 & 1.050 & 13.496 \\
\hline
\end{tabular}

According to the result of SPSS software output, it was found out that the t-test value was 2,359.And the result of t-table was 2,021, the significance level 0,05 , with degree of freedom (df) $22+22-2=42$, it means that the value of $t$-test was higher than t-table $(2,359>$ 2,021). From the value result, it showed that there was a significant effect on Spelling Bee game.

Based on the result showed above, the researcher found out the value sig (2-tailed) was 0.023 . The value sig $(2$-tailed) was lower than the significance level $(0.023<0.05)$. It means that the alternative hypothesis (Ha) was accepted and the null hypothesis (Ho) was rejected. 
From the value result, it showed that Spelling Bee Game is appropriate and effective for teaching Vocabulary.

\section{Discussion}

This research aimed to determine the effect of Spelling Bee Game in students' vocabulary achievement. The result of finding the pre-test and the post-test scores of both the experimental and control groups was different. The pre-test and post-test scores of both experimental groups were higher than the score of the pre-test and post-test in the control group. It was indicated that this game improved vocabulary achievement.

Qomariyah and Nafisah (2020) stated students who have high competence in memorizing vocabulary when the academic process is one of the results of applying good strategy. So, implementing Spelling Bee game is one of the alternative strategies in teaching vocabulary. Dealing with the research hypothesis that Spelling Bee affects students' vocabulary. It has proved with analysis of t-test is higher than t-table.

McCarten (2007) said in his theory that there are many ways to help students in learning vocabulary: (a) It is marking vocabulary subject clearly, (b). It is making how to target vocabulary can stand out, whether it is about practice or regularly review, (c). It is providing a list of vocabulary.

To uncover abilities used Spelling Bee game, feelings, and hope of children. Based on the result of the study, Spelling Bee game focused on how to make students feel joyful, comfortable, and have fun in the academic process, the students can develop their mind to recognize and combine the new vocabulary and students easily remember using Spelling Bee game.

There is an advantage and disadvantage when this game is applied. The advantages and disadvantages of the game can be described by researchers namely: (1) In learning material, students more interested in using Spelling Bee in teaching-learning vocabulary. If students felt interested in the material they would more be attention, they would be focused on the material and the teacher didn't face difficulty explaining more about the material. It made a chance for the students more interactive with each other, (2) Next is a disadvantage, these advantages were how made the students interested in Spelling Bee game. How teacher control when students were noisy and more active. How faced students who much moved and spoke a lot of. How spent little time because this game only gave students a chance to do with little time so the teacher didn't have much time to explain many vocabularies. So the problem was how the teacher can control this Spelling Bee game.

It can be seen that using Spelling Bee game is a good strategy in teaching English vocabulary, but every strategy has a positive and negative impact when applied it. In solving that point, the teacher has an important role to be creative in modifying themes especially vocabulary. To motivate students, the teacher should give a prize to the winning team in order to be better next time. Otherwise, another team should be improved in vocabulary mastery and could be the best team later.

\section{CONCLUSION}

This study could be concluded that Spelling Bee game has an effect in vocabulary achievement. In teaching-learning vocabulary using Spelling Bee game, the students are most interested. Before treatments, the students didn't know about this game. However, when they already got the treatment, they realized that Spelling Bee game could help them in recognizing new words. Seeing the benefit of Spelling Bee game, the students thought that this game was very useful for them so that the perception of the students was positive.

This study was conducted on the word Spelling Bee game in vocabulary achievement. The result showed that there was the effect of the students' vocabulary achievement between 
the experiment and control group. Based on the result, students' vocabulary achievement in the experiment group was better than the students in the control group. It means that teaching of Spelling Bee game could promote students' vocabulary achievement. This happens due to the fact that Spelling Bee game could help students to develop their vocabulary achievement.

\section{REFERENCES}

Asyiah, D. (2017). The Vocabulary Teaching and Vocabulary Learning: Perception, Strategies, and Influences on Student's Vocabulary Mastery. Jurnal Bahasa Lingua Scientia, 9(2), 293-318. https://doi.org/10.21274/ls.2017.9.2.293-318.

Cameron, L. (2001). Teaching Language to Young Learners. New York: Cambridge University Press.

Graves, M. (2008). What Research has to Say about Vocabulary Instruction. New York: International Reading Association.

Hiebert, E., \& Kamil, M. (2005). Teaching And Learning Vocabulary Bringing Research To Practice. London: Lawrence Erlbaum Associates.

Kagan, S. (2009). Kagan Cooperative Learning. San Clemente: Kagan Publishing.

Mayasari, N., \& Yuli, M. (2019). The Effect of Using Spelling Bee Games to Improve Students' Vocabulary Mastery in Using ICD 10 Chapter XVIII and XXI at APIKes IRIS Padang. Journal Polingua: Scientific Journal of Linguistics, Literature and Education, 8(2), 66-70. https://doi.org/10.30630/polingua.v8i2.115.

McCarten, J. (2007). Teaching Vocabulary Lesson from the Corpus, Lesson for the Classroom. New York: Cambridge University Press.

Nation, I. (1990). Teaching and Learning Vocabulary. Massachusetts: Heinle \& Heinle Publishers.

Ningrum, M., \& Indrawati, P. (2020). Improving Students' Vocabulary mastery Using Spelling Bee Game at Fifth Grade in SDIT Ya Bunayya Pujon. JOURNEY (Journal of English Language and Pedagogy) ,3(2), 66-73. https://doi.org/10.33503/journey.v3i2.956.

Nurpitasari, L., \& Wan, J. (2018). The Use of Spelling Bee Game to Increase the Students' Vocabulary Mastery of the Seventh Grade at SMPN 1 Bantan. INOVISH Journal, 3(20), 129-136. https://doi.org/10.35314/inovish.v3i2.828.

Qomariyah, S., \& Nafisah, B. (2020). Examining Think-Talk-Write (TTW) Strategy in Students' Vocabulary Mastery. JOLLT Journal of Languages and Language Teaching, 8(1), 72-82. https://doi.org/1033394/jollt.v8il.2240.

Read, J. (2000). Assessing Vocabulary. Cambridge: Cambridge University Press.

Rohmawati, A. (2015). Spelling Bee in Teaching Vocabulary. Journal of English and Education, 3(2), 1-15.

Sari, A., \& Fadly, A. (2018). The Effect of Using English Spelling Bee Game to Enrich the Vocabulary of the Second Year Students of SMPN 40 Pekanbaru. Jurnal Online Mahasiswa FKIP, 5(2), 1-11.

Sugiyono. (2016). Metode Penelitian Kuantitatif, Kualitatif dan R\&D. Bandung: PT Alfabet. Sugiyono. (2017). Metode Penelitian Kuantitatif Kualitatifdan $R \& D$. Bandung: Alfabeta.

Thornbury, S. (2002). How to teach vocabulary. Essex: Pearson Education Limited.

Wright, A. et al. (2006). Games for Language Learning. Cambridge: Cambridge University Press. 